\title{
Pengembangan Pembelajaran Daring Melalui Media Interaktif Simulasi Elektronik (MISE) pada Mata Kuliah Ekonomi Makro
}

\author{
Mayasari* \\ FKIP Pendidikan Ekkonomi, Universitas Batanghari \\ *Correspondence email: mhmayahendra@gmail.com
}

\begin{abstract}
Abstrak. Terdapat dua tujuan yang dicapai dalam penelitian ini diantaranya 1) menyusun perangkat pembuatan Pengembangan Pembelajaran Daring Melalui Media Interaktif Simulasi Elektronik Pada Mata Kuliah Ekonomi Makro; dan 2) mengukur atau mengetahui tingkat keakuratan Pengembangan Pembelajaran Daring Melalui Media Interaktif Simulasi Elektronik Pada Mata Kuliah Ekonomi. Metode penelitian yang digunakan adalah pendekatan Design Based Research (DBR) dan mahasiswa FKIP program Studi Pendidikan Ekonomi Universitas Batanghari sebagai subejek penelitian yang berjumlah 22 orang mahasiswa. Ada empat tahapan dalam Design Based Research (DBR) yang digunakan yakni 1 ) tahap I Analisis Permasalahan di lapangan; 2) tahap II Pengembangan Desain dan Prototipe Perangkat Pembelajaran Daring Melalui MISE; 3) tahap III Pengujian dan Penyempurnaan Prototipe Perangkat Pembelajaran Online Melalui MISE; dan 4) tahap IV Refleksi Produk Perangkat Pembelajaran. Teknik pengumpulan data mealui observasi, wawancara mendalam, dan Focus Group Discussion (FGD). Analisis data yang digunakan dalam mengolah hasil data penelitian ini mengunakan analisis kualitatif, kuantitatif, dan mix method. Penelitian ini menghasilkan produk pembelajaran Media Interaktif Simulasi Elektronik (MISE) yang dikemas dalam bentuk aplikasi Software Adobe Flash Profesional CS6 pada mata kuliah ekonomi makro dengan tingkat keakuratan menggunakan uji validasi ahli materi dan ahli media pembelajaran interaktif yang dapat diketahui bahwa hasil validasi ahli materi sebesar 4,5 atau baik dan hasil validasi ahli media sebesar 4,44 atau baik.
\end{abstract}

Kata Kunci: Pembelajaran Daring; MISE

Abstract. There are two objectives achieved in this research, including: 1) developing tools for developing online learning through electronic simulation interactive media in macroeconomics courses; and 2) measuring or knowing the level of accuracy of Online Learning Development Through Electronic Simulation Interactive Media in Economics Courses. The research method used is a Design Based Research (DBR) approach and 22 students of the Faculty of Education and Science of the Economic Education Study Program at Universitas Batanghari as research subjects. There are four stages in the Design Based Research (DBR) used, namely 1) stage I Analysis of Problems in the field; 2) Phase II Development of Online Learning Device Design and Prototype Through MISE; 3) stage III. Testing and Completing Prototypes of Online Learning Tools Through MISE; and 4) stage IV Reflection on Learning Device Products. Data collection techniques are through observation, in-depth interviews, and Focus Group Discussion ( FGD). Analysis of the data used in processing the results of this research data using qualitative, quantitative, and mix method analysis. This research produces an Electronic Simulation Interactive Media (MISE) learning product that is packaged in the form of the Adobe Flash Professional CS6 Software application for macroeconomics courses with an accuracy level using the validation test of material experts and interactive learning media experts which can be seen that the results of material expert validation are 4.5 or good and the result of media expert validation is 4.44 or good.

Keywords: Online Learning; MISE

\section{PENDAHULUAN}

Pandemi covid 19 melanda dunia sejak setahun belakangan ini, khususnya di Indonesia yang membuat ranah pendidikan merubah haluannya dari proses pembelajaran tatap muka menjadi tatap layar dengan menggunakan bantuan internet, sehingga beberapa pemerintah daerah memutuskan untuk menerapkan suatu kebijakan bagi instansi pendidikan termasuk sekolahsekolah dan mulai menerapkan metode belajar dengan sistem daring atau online. Sistem pembelajaran daring merupakan sistem pembelajaran tanpa tatap muka secara langsung antara pendidik dan peserta didik tetapi dilakukan melalui online yang menggunakan jaringan internet sebagai bentuk dari kemajuan teknologi saat ini. Kemajuan teknologi berupa adanya jaringan internet membawa perubahan yang sangat besar pada kehidupan manusia dalam proses pembelajaran. Kemajuan teknologi ini juga mendorong manusia untuk menciptakan penemuan-penemuan baru, salah satu penemuan yang membawa perubahan besar adalah penggabungan media elektronika pada pembelajaran. Dengan ditambahkannya media elektronika, pembelajaran bisa menjadi lebih praktis dan sederhana terlebih lagi pada masa pandemic covid 19 ini, salah satu contohnya adalah komputerisasi yang bisa membantu pembelajaran jarak jauh dengan menggunakan software zoom, google classroom, google meet, Whatsapp(WA), telegram dan lain sebagainya.

Keadaan sistem pembelajaran dengan menggunakan internet saat pandemi dialami juga pada jajaran pendidikan tinggi dimana banyak sekali keluhan dan kendala-kendala yang ditemukan ketika harus melakukan pembelajaran secara online seperti informasi dan komunikasi yang dinilai tidak begitu fleksibel 
karena menjadikan dosen kesulitan dalam menjelaskan materi/mengulang penjelasannya kepada mahasiswa yang belum paham dengan materi yang sudah diberikan, serta minimnya tanya jawab yang mungkin sulit dilakukan karena permasalahan jaringan ataupun berupa teks notice dalam penjelasan yang membuat perbedaan pemahaman antara mahasiswa yang satu dengan yang lainya

Teks notice yang terjadi dalam proses pembelajaran daring pada mahasiswa program studi pendidikan ekonomi FKIP Universitas Batanghari membuat dosen menjadi kewalahan karena kebanyakan mahasiswa mengabaikan instruksi-instruksi yang diberikan oleh dosen. Hal ini dikarenakan dosen tidak dapat memegang kendali saat proses belajar mengajar sedang berlangsung sehingga terjadinya ketidak selarasan komunikasi ataupun interaksi antara dosen dan mahasiswa menjadi tidak optimal. Dosen juga mengalami kesulitan untuk menciptakan suasana yang kondusif dikarenakan permasalahan yang kompleks saat pembelajaran daring berlangsung melalui media elektronik. Seharusnya melalui media elektronik ini akan dapat meningkatkan interaktif antara dosen dan mahasiswa. Seharusnya dalam proses pembelajaranya mereka dapat melakukan simulasi pembelajaran yang dianggap perlu dilakukan sesuai materi pembelajaranya. Dosen juga dapat memastikan mahasiswa mengikuti pembelajaran dalam waktu yang bersamaan, meskipun ditempat yang berbeda. Hal ini pun menjadi permasalahan yang sangat penting bagi mahasiswa, mengingat jam berapa mereka harus belajar dan bagaimana kuota data yang mereka miliki, sedangkan orang tua mereka berpenghasilan rendah atau kalangan menengah kebawah (kurang mampu). Hingga akhirnya hal seperti ini terbebani kepada orang tua mahasiswa yang ingin anaknya tetap mengikuti pembelajaran daring, karena bagaimanapun juga orang tua dituntut untuk memaksimalkan peranannya untuk mendampingi anak-anaknya agar mendapatkan pendidikan yang layak, yang bisa didapatkan dalam proses pembelajaran yang menjadi kunci keberhasilan.

Untuk memenuhi tujuan dari pendidikan tinggi dalam mencetak tenaga pengajar yang kompeten, mahasiswa program studi pendidikan ekonomi diwajibkan untuk memenuhi standar kompetensi yang harus dicapai. Salah satu mata kuliah inti yang ada pada Program Studi Pendidikan Ekonomi adalah mata kuliah Ekonomi Makro dengan memiliki bobot 3 sks. Mata kuliah ini wajib untuk ditempuh mahasiswa pendidikan ekonomi karena erat hubungannya dengan perkembangan perekonomian secara makro yang dijalankan dengan menggunakan bantuan internet dimasa pandemic ini. Media elektronik pembelajaran yang dilakukan dalam pembelajaran mata kuliah ekonomi makro bagi mahasiswa pendidikan ekonomi saat ini lebih banyak dilakukan dengan metode ceramah, tanya jawab, demonstrasi, dan penugasan melalui elektronik handphone, computer, note book, dan laptop yang menggunakan softwhare media social seperti google meet, Whatsapp(WA), telegram dan lain sebagainya. Metode ini cukup efektif di masa pandemic ini, tetapi belum cukup apabila menginginkan pembelajaran yang menuntut mahasiswa untuk lebih aktif dan mandiri.

Masalah lain dalam proses pembelajaran ini juga tidak dapat dipersingkat untuk menghemat waktu, ketepatan waktu saat harus mengumpulkan tugas yang diberikan karena terkendala dengan kuota, kurangmya konsenterasi saat dalam memahami materi ketika harus berdiskusi, sehingga sebagian besar dari mereka tidak merespon dengan baik terkait dengan instruksi yang sudah diberikan oleh dosen ketika proses belajar dan mengajar sedang berlangsung. Hal ini dikarenakan dosen harus selalu memberi petunjuk-petunjuk untuk mahasiswa. Tentu saja hal ini sangat kurang efektif dalam penguasaan mata kuliah ekonomi makro. Oleh karena itu, penggunaan media pembelajaran interaktif simulasi elektronik dapat digunakan sebagai salah satu solusi media pembelajaran dinilai sangat tepat. Pembelajaran dengan metode media pembelajaran berbasis interaktif simulasi elektronik akan lebih efektifefisien, dan menarik sehingga meningkatkan motivasi dan membuat minat serta mengambil perhatian mahasiswa untuk fokus mengikuti materi, sehingga diharapkan efektifitas belajar mahasiswa akan meningkat.

Masalah-masalah yang dialami oleh dosen dan mahsiswa saat pembelajaran daring apabila tidak segera diatasi tentunya akan menghambat proses pembelajaran dan akan berdampak pada pencapaian tujuan dari belajar tersebut. Jika terdapat mahasiswa yang mempunyai permasalahan tersebut tidak segera ditemukan solusinya, maka mahasiswa akan mengalami kegagalan atau kesulitan belajar yang mengakibatkan rendahnya indeks prestasi akaademik, minat belajar atau tidak dapat melanjutkan belajar. Untuk itu maka seorang dosen hendaknya harus mengetahui kondisi mahasiswa agar tercipta proses pembelajaran yang baik dan kondusif, serta dapat menciptakan pembelajaran yang interaktif ssehingga tumbuh minat mahasiswa untuk belajar walaupun dilakukan secara daring.

Dari penjelasan yang telah di paparkan, maka perlu adanya suatu inovasi dalam media yang digunakan dalam pembelajaran ekonomi makro melalui media interaktif simulasi elektronik yang dikembangkan dalam pembelajaran. Sehingga yang menjadi tujuan diadakan penelitian ini adalah untuk 1) menyusun perangkat pembuatan Pengembangan Pembelajaran Daring Melalui Media Interaktif Simulasi Elektronik Pada Mata Kuliah Ekonomi Makro; dan 2) mengukur atau mengetahui tingkat keakuratan Pengembangan Pembelajaran Daring 
Melalui Media Interaktif Simulasi Elektronik Pada Mata Kuliah Ekonomi.

\section{Kajian Teori \\ Konsep Pembelajaran Daring}

Pembelajaran daring sering kita dengar pada saat pandemic covid-19 santer dan merebak di seluruh penjuru dunia, padahal pembelajaran daring sudah ada sebelum wabah pandemic covid-19 muncul sebagai wadah untuk mempermudah proses pembelajaran di era teknologi saat ini. kata pembelajaran juga mengandung makna yang lebih pro-aktif dalam melaksanakan kegiatan belajar, sebab di dalamnya bukan hanya pendidik atau instruktur yang aktif, tetapi peserta didik merupakan subjek yang aktif dalam belajar (Hamzah dan Lamatenggo, 2011). Menurut Nurdyansyah dan Fahyuni (2016) Pembelajaran merupakan suatu proses interaksi antara guru dengan siswa, baik interaksi secara langsung maupun secara tidak langsung.

Lebih lanjut Setiawan (2017) mengemukakan bahwa pembelajaran daring merupakan suatu system pembelajaran sebagai sarana proses mengajar yang dilaksanakan tanpa harus bertatap muka dengan secara langsung antara guru dengan siswa. Sedangkan Sadikin dan Hamidah (2020) pembelajaran daring dapat diartikan sebagai pembelajaran yang menggunakan jaringan internet dengan aksesibilitas, konektivitas, fleksibilitas dan memampuan untuk memunculkan berbagai jenis interaksi pembelajaran. Dalam proses pembelajaran yang dilakukan secara luring ataupun daring tentunya akan mempunyai kelemahan dan kelebihan. Adapun kelemahan pembelajaran daring yaitu 1) Sulit untuk mengontrol siswa mana yang serius dalam mengikuti pelajaran ataupun tidak, 2) Pembelajaran lebih banyak bersifa teoritis ksrena tidak dimungkinkan adanya interaksi langsung dengan siswa, 3) Materi pembelajaran sulit didapat system belajar daring memang lebih menghemat waktu, tetapi belum tentu belajar daring lebih efektif dalam penerimaan materi pembelajran bagi siswa, 4) Koneksi jaringan yang buruk dapat menghambat proses belajar siswa sehingga tidak fokus dalam mengikuti pembelajaran, 5) Menghabiskan banyak data internet/kuota. Sedangkan kelebihan dari pembelajaran daring antara lain 1) Membuat siswa menjadi mandiri dalam belajarkarena dapat belajar dimana saja mereka berada, baik dalam ruangan maupun diluar ruangan, 2) Siswa tidak perlu mencatat materi karena berkas akan tersimpan secara otomatis pada file ternama sesuai dengan aplikasi yang digunakan, 3) Waktu belajar lebih singkat karena siswa dapar mengakses materi pembelajaran dengan mudah, 4) Siswa merasa lebih rileks dan tidak tegang dalam mengikuti proses pembelajaran, dan 5) Siswa merasa punya lebih banyak waktu dirumah bersama keluarga (Setiawan, 2017)
Uraian tentang konsep pembelajaran daring tersebut dapat disimpulkan bahwa pembelajaran daring merupakan suatu system pembelajaran, dimana dalam prosesnya membutuhkan bantuan elektronik untuk mengoprasikanya tanpa harus bertatap muka dengan secara langsung antara pendidik dengan peserta didik. Pembelajaran daring tersebut ditujukan untuk mempermudah kegiatan proses pembelajaran sehingga yang menjadi tujuan pembelajaran bisa tercapai.

\section{Konsep Media Pembelajaran Interaktif Simulasi Elektronik (MISE)}

Sesuai dengan tingkatan kemampuan seseorang dalam belajar, maka dalam pembelajaran membutuhkan suatu media untuk melengkapi dan mempermudah pembelajaran. Robert Hanick dalam (Umar, 2014) mendefinisikan media adalah sesuatu yang membawa informasi antara sumber (source) dan penerima (receiver) informasi. Sanaky (2013) media pembelajaran adalah sarana atau alat bantu pendidikan yang dapat digunakan sebagai perantara dalam proses pembelajaran untuk mempertinggi efektifitas dan efisiensi dalam mencapai tujuan pengajaran. Media pembelajaran merupakan suatu teknologi pembawa pesan yang dapat digunakan untuk keperluan pembelajaran, media pembelajaran merupakan sarana fisik untuk menyampaikan materi pelajaran. Media pembelajaran merupakan sarana komunikasi dalam bentuk cetak maupun pandang dan dengar termasuk teknologi perangkat keras (Rusman, Kurniawan, dan Riyana, 2013). Sedangkan menurut Atapukang (2016) media pembelajaran adalah segala sesuatu yang dapat menyampaikan atau menyalurkan pesan dari suatu sumber secara terencana, sehingga terjadi lingkungan belajar yang kondusif dimana penerimanya dapat melakukan proses belajar secara efesien dan efektif.

Menurut Rudy Brets dalam (Ekayani, 2017) ada 7 (tujuh) klasifikasi komponen media pembelajaran, yaitu: 1) Media audio visual gerak, seperti: film suara, pita video, film, tv. 2) Media audio visual diam, seperti: film rangkai suara, halaman suara. 3) Audio semi gerak seperti: tulisan jauh bersuara. 4) Media visual bergerak, seperti: film bisu. 5) Media visual diam, seperti: halamman cetak, foto, microphone, slide bisu. 6) Media audio, seperti: radio, telepon, pita audio 7) Media cetak, seperti: buku, modul, bahan ajar mandiri. Arsyad (2013) mengemukakan bahwa berdasarkan perkembangan teknologi, media pembelajaran dapat dikelompokkan ke dalam empat komponen, yaitu 1) media hasil teknologi cetak, 2) media hasil teknologi audio-visual, 3) media hasil teknologi yang berdasarkan komputer, dan 4) media hasil gabungan teknologi cetak dan komputer. Selain memiliki komponen, media pembelajaran juga mempunyai fungsi diantaranya 1) Memperjelas pesan agar tidak terlalu verbalistis 2) Mengatasi keterbatasan ruang, waktu tenaga dan daya indra. 3) Menimbulkan 
gairah belajar, interaksi lebih langsung antara murid dengan sumber belajar. 4) Memungkinkan anak untuk belajar mandiri sesuai dengan bakat dan kemampuan visual, auditori dan kinestetiknya. 5) Memberi rangsangan yang sama, mempersamakan pengalaman dan menimbulkan persepsi yang sama. 6) Proses pembelajaran mengandung lima komponen komunikasi, guru (komunikator), bahan pembelajaran, media pembelajaran, siswa (komunikan), dan tujuan pembelajaran (Daryanto, 2013)

Masih menurut Daryanto (2013) mendefinisikan media pembelajaran interaktif atau multimedia pembelajaran sebagai aplikasi multimedia yang digunakan dalam proses belajar mengajar, yang berarti multimedia pembelajaran berfungsi menyalurkan (pengetahuan, ketrampilan, dan sikap), merangsang pilihan, perasaaan, perhatian dan kemauan siswa, sehingga dapat mencapai tujuan pembelajaran. Menurut Ikhwandi dan Basri (2020) Media pembelajaran interaktif merupakan media yang menggabungkan beberapa komponen seperti gambar, foto, teks, audio, dan video yang ditata secara menarik serta dilengkapi dengan fitur interaktif agar penggunanya dapat berinteraksi dengan media tersebut.

Tarigan dan Siagian (2015) mengatakan bahwa perlu adanya kreativitas pendidik dalam memanfaatkan media dalam proses pembelajaran agar pembelajaran lebih menarik dan tidak cenderung membosankan. Penggunaan media interaktif muncul dan berkembang berdasarkan permasalahan dalam proses pembelajaran seperti kejenuhan dan kurang komunikatifnya penyampaian materi dalam belajar. Sedangkan Suryowinoto (2020) dalam penelitian yang dilakukanya media pembelajaran interaktif yang dimaksudkan adalah media pembelajaran menggunakan komputer sebagai media penyampai pembelajaran dua arah atau ada umpan balik antara media pembelajaran itu dengan pengguna seperti pengubahan variabel nilai atau mensimulasikan perubahan tersebut sesuai fungsinya. . Sehingga dapat disimpulkan bahwa media interaktif simulasi elektronik (MISE) adalah media pembelajaran berbantuan computer menggunakan bantuan perangkat lunak dalam hal ini adalah Software Adobe Flash Profesional CS6 sebagai media penyampai pembelajaran dua arah sehingga proses pembelajaran menjadi interaktif.

\section{Konsep Mata Kuliah Ekonomi Makro}

Ilmu makro ekonomi merupakan salah satu cabang dari ilmu ekonomi. Makro ekonomi berfokus pada perilaku dan kebijakan ekonomi yang dapat mempengaruhi tingkat konsumsi dan investasi, neraca perdagangan dan pembayaran suatu negara, faktor-faktor penting yang mempengaruhi perubahan harga dan upah, kebijakan fiskal dan moneter, jumlah uang yang beredar, tingkat suku bunga dan jumlah utang negara. Makro ekonomi adalah salah satu cabang ilmu ekonomi yang membahas perilaku perekonomian secara agregat, misalnya kemakmuran dan resesi, output barang dan jasa, total perekonomian, laju pertumbuhan output, laju inflasi dan pengangguran, neraca pembayaran dan juga nilai kurs (Dornbusch dan Stanley, 1996).

Di setiap negara di dunia ini tentu kegiatan perekonomiannya tidak selalu stabil, apalagi dengan ruang lingkup yang sangat luas setiap negara pasti mempunyai kendala ataupun masalah tersendiri. Namun bila diklasifikasikan lagi masalah masalah yang dihadapi oleh tiap negara di dunia dapat dikelompokkan menjadi 3 masalah pokok. Menurut Bakti, Rakhmat, dan Syahrir (2010) kebijakan makro ekonomi yang dilakukan oleh pemerintah sebagai keiikutsertaan pemerintah dalam memacu kehidupan ekonomi selalu dihadapkan kepada masalah pertumbuhan, inflasi, dan pengangguran sebagai central issues macroeconomic. Dengan kata lain bahwa yang menjadi masalah pokok dalam ekonomi makro dan mencakup keseluruhan variabel variabel dalam ekonomi makro adalah masalah pertumbuhan, inflasi dan pengangguran.

Kebijakan ekonomi yang dirumuskan oleh pemerintah tentu harus disesuaikan dengan tujuan ataupun target apa yang harus dicapai dengan kebijakan yang akan dibuat tersebut. Oleh karena itu sebelum memutuskan kebijakan apa yang harus digunakan dalam perekonomian harus terlebih dahulu ditentukan target dan tujuan yang hendak dicapai, sehingga dalam pelaksanaan kebijakan tersebut dapat berjalan sesuai dengan yang diharapkan. Secara umum ada beberapa aspek yang menjadi tujuan kebijakan makroekonomi dan merupakan pilihan tersendiri bagi setiap Negara. Hal ini diakibatkan oleh berbedanya tujuan dan sasaran ekonomi suatu Negara tergantung pada kondisi dan keadaan ekonomi di Negara tersebut. Tujuan yang dimaksudkan antara lain: Menciptakan Tingkat Harga yang Stabil, Memaksimalkan Tenaga Kerja dan Output Menciptakan Pertumbuhan Ekonomi, Mengukuhkan Neraca Pembayaran (Stabilitas Neraca Pembayaran).

Mata Kuliah ini bertujuan memberikan pendalaman tingkatan menengah (intermediate) teori ekonomi makro, dan meliputi pokok-pokok bahasan utama baik dalam perekonomian tertutup maupun terbuka, antara lain perihal, indikator-indikator ekonomi makro seperti produk domestik bruto, kesempatan kerja dan pengangguran, inflasi, keseimbangan eksternal dan pembentukan nilai tukar. Mata Kuliah ini juga memberikan pemahaman tentang elemen-elemen pembentuk permintaan dan penawaran agregatif, teori pertumbuhan ekonomi serta kebijakan ekonomi, baik fiskal maupun moneter serta dampaknya terhadap perekonomian. Studi kasus tentang dampak kebijakan ekonomi terhadap perekonomian Indonesia juga menjadi bagian dari mata kuliah ini. 


\section{METODE}

Penelitian pengembangan pembelajaran daring melalui media interaktif simulasi elektronik (MISE) dengan menggunakan pendekatan Design Based Research (DBR). Pendekatan design based research (DBR) merupakan model pengembangan yang bersifat fleksibel disesuaikan dengan kebutuhan-kebutuhan warga belajar yaitu mahasiswa. Menurut Abdallah (2011) menyatakan DBR adalah

"a new paradigm or methodology in educational research that is based on both theory and previous research with the aim of improving educational practice. It is conducted in the real, complex, and messy learning/teaching contexts through iterative cycles of analysis, design, development, and implementation mediated by some interventions. It originates from real educational problems and/or challenges supported by educational theories, and ends with design principles and/or learning 6 theories subject to continuous refinement and improvement. Thus, the products/outputs of DBR are design principles, learning theories, interventions, curricular products, instructional tools, and/or practical solutions/prescriptions".

Design Based Research (DBR) yang akan dipakai dalam pengembangan pembelajaran daring melalui media pembelajaran interaktif simulasi elektronik (MISE) ini mengadopsi model design based research yang dikemukakan Reeves (2000) dengan Model original Design Based Research (DBR) yang tertuang dalam gambar berikut:

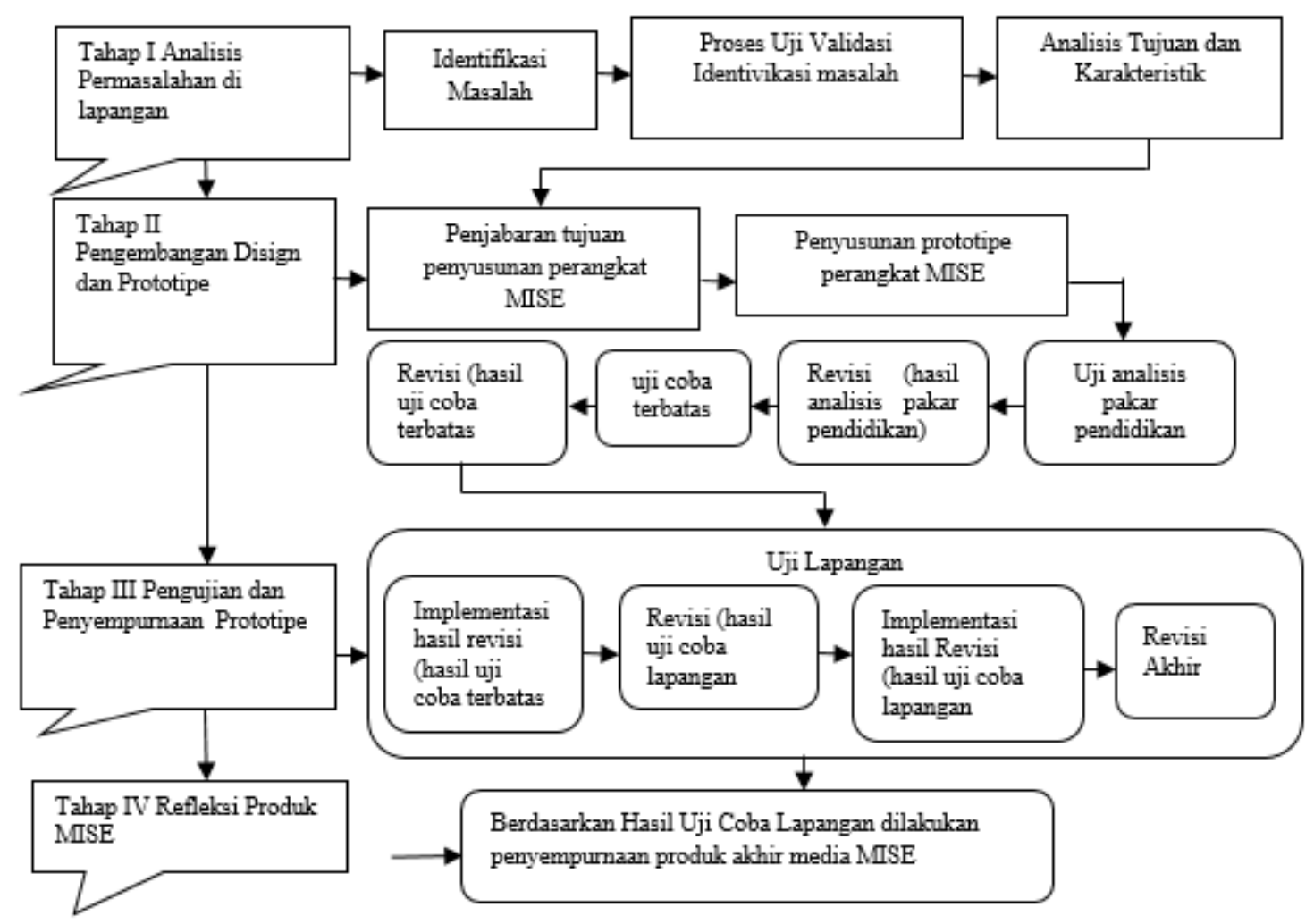

Gambar 1. Prosedur pengembangan Pembelajaran Daring Melalui MISE

Subjek penelitian pengembangan ini adalah mahasiswa FKIP program Studi Pendidikan Ekonomi Universitas Batanghari yang berjumlah 22 orang mahasiswa. Pengumpulan data dalam penelitian ini menggunakan metode observasi, wawancara mendalam, dokumentasi, FGD (focus group discussion), dan kuesioner (angket). Analisis data yang digunakan oleh peneliti dalam mengolah data penelitian dan pengembangan ini mengunakan analisis data kualitatif, analisis data kuantitatif, dan mix method.

\section{HASIL DAN PEMBAHASAN}

Hasil penelitian dan pengembangan ini adalah produk media pembelajaran MISE yang dikemas dalam bentuk aplikasi software perangkat elektronik Software Adobe Flash Profesional CS6 dengan materi pada mata kuliah ekonomi makro. Penelitian dan pengembangan ini dilaksanakan dengan mengacu pada tahapan penelitian dan pengembangan menurut Reeves (2000) memaparkan ada empat tahap dalam penelitian dan pengembangan. Adapun keempat tahap penelitian dan pengembangan ini meliputi: 


\section{Tahap I Analisis Permasalahan di lapangan}

Tahap pertama adalah tahap Analisis Permasalahan di lapangan Pada analisis terdapat 2 tahapan Needs Assessment (Analisis Kebutuhan) berupa analisis keadaan lapangan dan peserta serta pengumpulan referensi materi yang akan dijadikan pokok bahasan dalam pengembangan media. Hasil informasi mengenai proses pembelajaran, karakteristik mahasiswa dan pengembangan media pembelajaran yang diperoleh dari kegiatan observasi yang dilakukan saat melaksanakan proses pembelajaran ekonomi makro. Kegiatan selanjutnya tahap Front-end Analysis dengan cara mengumpulkan referensi berupa kurikulum, satuan acara pembelajaran (SAP) mata kuliah ekonomi makro, serta buku-buku yang berkaitan dengan materi dan lainlain yang dibutuhkan dalam pengembangan media pembelajaran. Hasil dari analisa terhadap kurikulum, maka dipilih Standar Kompetensi (SK) dan Kompetensi Dasar (KD) tentang ekonomi makro yang menjadi sasaran pengembangan.

Pengumpulan informasi dilakukan tinjauan standar isi yang meliputi Standar Kompetensi (SK) dan Kompetensi Dasar (KD) dan studi pustaka. Setelah tahap pengumpulan informasi selesai, selajutnya dilakukan tahap perencanaan. Pada tahap ini dilakukan pembuatan kisi-kisi instrumen penelitian dan pembuatan instrumen penelitian. Kisi-kisi instrumen penelitian dibuat dengan berpedoman pada kriteria mengevaluasi media pembelajaran menurut Walker dan Hess. Kriteria penilaian media menurut Walker dan Hess (1984) menjadi pedoman dalam pembuatan kisi-kisi instrumen lembar validasi, lembar observasi dan pedoman wawancara. Kisi-kisi instrumen yang telah selesai dibuat selanjutnya menjadi pedoman dalam pembuatan instrumen penelitian.

\section{Tahap II. Pengembangan Desain dan Prototipe Perangkat Pembelajaran Daring Melalui MISE}

Tahap kedua adalah Pengembangan Desain dan Prototipe Perangkat Pembelajaran Daring Melalui MISE. Pada tahap ini dilakukan perancangan media pembelajaran interaktif yang meliputi beberapa langkah yakni langkah pertama dalam mendesain pengembangan pembelajaran daring melalui media interaktif simulasi elektronik (MISE) yaitu dengan cara menetapkan pengetahuan, sikap dan perilaku yang dimiliki mahasiswa setelah mempergunakan media pembelajaran dengan teknik AuBeCoDe (Audience, Behavior, Condition, Degree). Maksud dari teknik tersebut yaitu 1) Audience adalah suatu arahan yang yang diajukan untuk fokus pada apa yang harus dilakukan atau dikerjakan mahasiswa; 2) Behavior adalah suatu sikap atau tingkah laku kita dalam aktivitas pembelajaran untuk mendeskripsikan kemampuan baru yang harus dimiliki mahasiswa setelah proses pembelajaran dan harus dapat diukur; 3) Condition merupakan suatu kondisi yang dibutuhkan untuk dapat menunjukan kompetensi atau tujuan pembelajaran dan sebuah pernyataan tujuan pembelajaran harus memperturutkan kondisi dimana aktivitas kinerja mahasiswa akan dinilai; dan 4) Degree adalah pernyataan tujuan yang menandai suatu standar atau kriteria sebagai dasar pengukuran tingkat keberhasilan pembelajaran bagi mahasiswa. Adapun hasil dari rumusan tujuan pengembangan pembelajaran daring melalui media interaktif simulasi elektronik (MISE) adalah sebagai berikut:

1. Adanya media interaktif simulasi elektronik (MISE) dalam proses pembelajaran daring bagi mahasiswa program studi pendidikan ekonomi FKIP Universitas Batanghari dapat memahami materi yang disajikan dalam mata kuliah ekonomi makro.

2. Adanya media interaktif simulasi elektronik (MISE) mahasiswa program studi pendidikan ekonomi FKIP Universitas Batanghari dapat lebih aktif dalam belajar daring tentang ekonomi makro.

3. Dengan diterapkanya media interaktif simulasi elektronik (MISE) dalam pembelajaran daring pada mata kuliah ekonomi makro, mahasiswa program studi pendidikan ekonomi FKIP Universitas Batanghari dapat mempelajari materi yang disajikan dalam mata kuliah tersebut dimanapun dan kapanpun.

Langkah kedua melakukan pembuatan flowchart, dimana flowchart ini suatu diagram yang dipergunakan untuk mendeskripsikan alur dari proses pembelajaran daring melalui media interaktif simulasi elektronik (MISE). Adapun flowchart yang disajikan dalam penelitian ini mengenai media interaktif simulasi elektronik (MISE) dapat dilihat pada bagan berikut: 


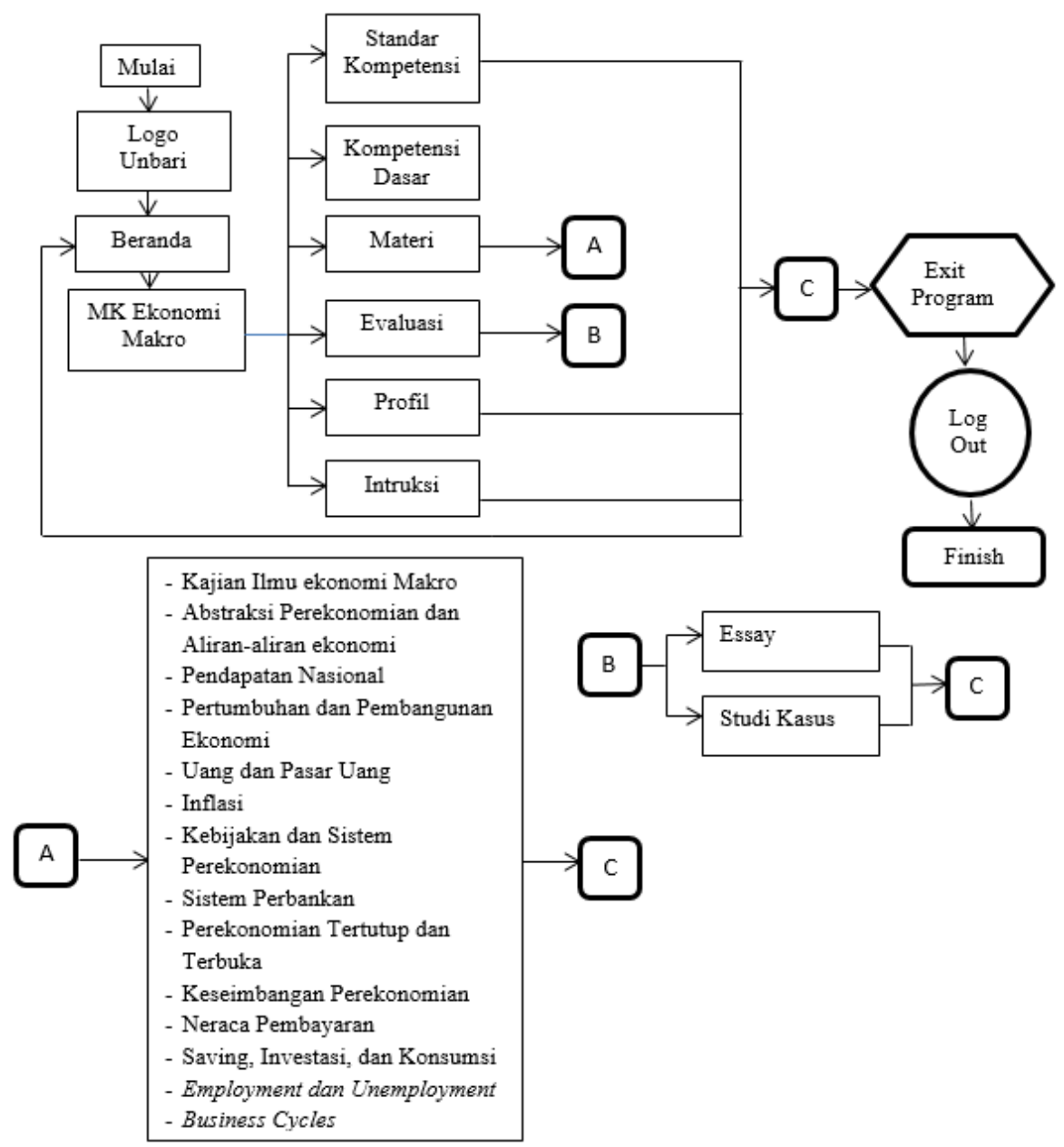

Gambar 2. Flowchart MISE

Langkah ketiga melakukan pembuatan storyboard, dimana storyboard merupakan deskripsi dalam pembuatan media interaktif simulasi elektronik (MISE) yang dibuat untuk melancarkan proses pembuatan sebuah produk. Langkah keempat yang dilakukan adalah pengumpulan objek berdasarkan dengan konsep dan rancangan yang telah dibuat. Tahapan pengumpulan objek yang harus dilakuakan yaitu:

1. Melakukan pengumpulan materi, soal tes atau evaluasi dan jawabanya, serta pembuatan desain MISE. Dalam menyusun materi harus disesuaikan dengan referensi atau sumber-sumber yang ada dan dibuat secara runut untuk mempermudah mahasiswa dalam mempelajari materi. Evaluasi dan jawaban ditulis dengan menggunakan bantuan notepad supaya dosen bisa merubahnya.

2. Mengumpulkan gambar, audio, video, tombol dan lainya. Gambar diambil dari berbagai referensi yang kemudian diunduh dan disesuaikan dengan materi ekonomi makro, selanjutnya di import kedalam media pembelajaran untuk mendukung materi. Vidio berupa kejadian-kejadian perekonomian makro terkini, sedangkan audio berupa music instrumental yang dibuat secara menarik dan enak didengar mahasiswa dengan menggunakan media interaktif simulasi elektronik dalam pembelajaran daring. Tombol A,B, dan $\mathrm{C}$ dibuat sesuai dengan kebutuhan untuk mempermudah pembelajaran. Semua objek diproses dengan menggunakan bantuan software perangkat elektronik Software Adobe Flash Profesional CS6 untuk dijadikan media pembelajaran interaktif.

Langkah terakhir melakukan penyusunan instrument uji kelayakan, dimana dalam pengujianya menggunakan angket yang disajikan kepada ahli media, ahli materi, dan mahasiswa sebagai responden dengan memilih tipe jawaban diberi tanda check list (V). Sebelum dilakukan penyajian angket terlebih dahulu melakukan pembuatan kisi-kisi instrumen penelitian yang menjadi kriteria penilaian media pembelajaran interaktif. Kisi-kisi instrumen yang telah selesai dibuat lalu dikembangkan menjadi instrumen penelitian. Instrumen penelitian yang akan digunakan adalah lembar validasi, lembar observasi dan pedoman wawancara. Lembar validasi digunakan untuk mengetahui kelayakan media pembelajaran MISE berdasarkan penilaian ahli materi dan ahli dalam media pembelajaran. Ahli materi memberikan penilaian berdasarkan aspek materi, pembelajaran, dan kebahasaan sedangkan ahli media pembelajaran memberikan penilaian berdasarkan aspek 
pemrograman dan tampilan media pembelajaran. Lembar observasi dan pedoman wawancara digunakan untuk mengetahui respon dan tanggapan dosen serta mahasiswa mengenai penggunaan media pembelajaran MISE di dalam kelas. Validasi instrumen dilakukan oleh validator yang ahli dalam bidang materi dan media pembelajaran.

\section{Tahap III. Pengujian dan Penyempurnaan Prototipe Perangkat Pembelajaran Daring Melalui MISE}

Tahap ketiga adalah Pengujian dan Penyempurnaan Prototipe Perangkat Pembelajaran Online Melalui MISE. Pada tahap ini dilakukan pengujian dan penyempurnaan dalam pembuatan media pembelajaran interaktif dari semua komponen yang telah disiapkan menjadi satu kesatuan yang utuh sesuai dengan flowchart dan storyboard yang telah dirancang menggunakan Adobe Flash Profesional CS6. Setelah media selesai dibuat dilakukan validasi oleh dosen ahli media dan dosen ahli materi, untuk memperoleh masukan terhadap pengembangan disertai dengan instrument penilaian kelayakan media pembelajaran interaktif.

Pengujian dan Penyempurnaan Prototipe Perangkat Pembelajaran Online Melalui MISE terdiri dari pembuatan story board, pembuatan layout, penulisan materi, dan penambahan efek suara video, animasi dan gambar. Setelah pengembangan produk selesai, maka diperoleh MISE yang dikemas dalam bentuk aplikasi software perangkat elektronik Software Adobe Flash Profesional CS6 pada materi yang ada pada mata kuliah ekonomi makro. Produk awal MISE yang dikemas dalam bentuk aplikasi software perangkat elektronik Software Adobe Flash Profesional CS6 selanjutnya divalidasi oleh ahli materi dan ahli media pembelajaran interaktif. Hasil validasi diperoleh dengan cara penilaian melalui lembar validasi yang diolah dengan bantuan computer SPSS for Windows versi 25 . Adapun hasil validasinya dapat dilihat pada tabel berikut:

Tabel 1. Uji Validitas Istrumen Materi Ekonomi Makro

\begin{tabular}{|l|r|r|r|r|}
\hline & $\begin{array}{c}\text { Item-Total Statistics } \\
\text { Scale Mean if } \\
\text { Item Deleted }\end{array}$ & $\begin{array}{c}\text { Scale Variance } \\
\text { if Item Deleted }\end{array}$ & $\begin{array}{c}\text { Corrected Item- } \\
\text { Total } \\
\text { Correlation }\end{array}$ & $\begin{array}{c}\text { Cronbach's } \\
\text { Alpha if Item } \\
\text { Deleted }\end{array}$ \\
\hline VAR00001 & 63.48 & 26.988 & .742 & .880 \\
VAR00002 & 63.48 & 27.715 & .493 & .889 \\
VAR00003 & 63.74 & 27.565 & .530 & .887 \\
VAR00004 & 63.48 & 26.988 & .742 & .880 \\
VAR00005 & 63.48 & 27.715 & .493 & .889 \\
VAR00006 & 63.48 & 26.988 & .742 & .880 \\
VAR00007 & 63.48 & 27.715 & .493 & .889 \\
VAR00008 & 63.74 & 27.565 & .530 & .887 \\
VAR00009 & 63.48 & 26.988 & .742 & .880 \\
VAR00010 & 63.48 & 27.715 & .493 & .889 \\
VAR00011 & 63.61 & 26.522 & .484 & .892 \\
VAR00012 & 63.61 & 26.522 & .484 & .892 \\
VAR00013 & 63.48 & 26.988 & .742 & .880 \\
VAR00014 & 63.48 & 27.715 & .493 & .889 \\
VAR00015 & 63.74 & 27.565 & .530 & .887 \\
\hline
\end{tabular}

Berdasarkan tabel di atas dapat diketahui bahwa item untuk materi ekonomi makro dengan jumlah item 15 dan jumlah responden mahasiswa 22 orang maka nilai $\mathrm{r}$ tabelnya sebesar 0,404 sedangkan nilai $\mathrm{r}$ hitungnya dilihat dari Corrected Item-Total Correlation lebih dari 0,404. Sehingga dapat disimpulkan bahwa $r$ hitung $>\mathrm{r}$ tabel dengan taraf signifikansi 0,05. Oleh sebab itu, maka penilaian materi diolah kembali yang diajukan pada ahli materi untuk validasi awal dan akhir. Adapun penilaian Hasil penilaian validasi awal dan akhir dari ahli materi dapat dilihat pada tabel 2 dan tabel 3 berikut:

Tabel 2. Penilaian Awal Aspek Kualitas Materi oleh Ahli Materi

\begin{tabular}{lll}
\hline No & Indikator & Skor \\
\hline 1 & Kesesuaian Materi dengan SK dan KD & 4 \\
2 & Kebenaran Konsep & 3 \\
3 & Keterkinian Materi & 4 \\
4 & Kejelasan Materi & 3 \\
5 & Ketercukupan materi untuk mencapai tujuan pembelajaran & 5 \\
6 & Keruntutan dalam penyampaian materi & 4 \\
7 & Ketepatan pemilihan gambar untuk menjelaskan materi & 4 \\
8 & Ketepatan pemilihan animasi untuk menjelaskan materi & 3 \\
9 & Ketepatan pemilihan video untuk menjelaskan materi & 4 \\
10 & Kelayakan contoh untuk memperjelas materi & 5 \\
11 & Kelayakan informasi tentang materi matematika ekonomi & 3 \\
12 & Kesesuaian soal dengan materi & 3 \\
13 & Tingkat kesulitan soal & 4 \\
14 & Materi mudah dipahami & 4 \\
15 & Ketepatan penggunaan bahasa dan ejaan & 4 \\
& Jumlah Skor & 57 \\
& Rata-Rata & 3,8 \\
\hline
\end{tabular}

Tabel 3. Penilaian Akhir Aspek Kualitas Materi oleh Ahli Materi

\begin{tabular}{lll}
\hline No & Indikator & Skor \\
\hline 1 & Kejelasan petunjuk belajar & 5 \\
2 & Ketepatan pemilihan materi yang dimediakan & 4 \\
3 & Kemudahan pemilihan menu belajar & 5 \\
4 & Kerlevanan sebagai media pembelajaran & 5 \\
5 & Penguatan positif untuk jawaban benar & 4 \\
6 & Penguatan positif untuk jawaban salah & 4 \\
7 & Pemberian umpan balik terhadap siswa & 5 \\
8 & Kemenarikan materi untuk dipelajari & 4 \\
9 & Pemberian latihan soal untuk pemahaman konsep siswa & 4 \\
10 & Penggunaan media memotivasi siswa untuk fokus dalam & 5 \\
& pembelajaran & 45 \\
& Jumlah Skor & 4,5 \\
\hline
\end{tabular}

Ahli materi memvalidasi sebanyak satu kali, hal ini disebabkan oleh rerata skor hasil validasi materi yang menunjukkan nilai sebesar 4,5 yang termasuk kategori baik sehingga media pembelajaran interaktif sudah memenuhi standar untuk diujicobakan. Ahli media pembelajaran interaktif memvalidasi sebanyak dua kali. Hal ini disebabkan oleh rerata skor hasil validasi ahli media tahap I masih menunjukkan nilai sebesar 3,8 termasuk kategori cukup baik sehingga belum memenuhi standar untuk diujicobakan. MISE yang dikemas dalam bentuk aplikasi software perangkat elektronik Software Adobe Flash Profesional CS6 selanjutnya direvisi sesuai 
saran dan komentar ahli materi dan ahli media pembelajaran interaktif.

MISE yang dikemas dalam bentuk aplikasi software perangkat elektronik Software Adobe Flash Profesional CS6 yang telah direvisi, divalidasi kembali oleh ahli media. Validasi oleh ahli media pada tahap II ini menunjukkan hasil yang dapat dilihat pada tabel 4 berikut:

Tabel 4. Penilaian Ahli Media Pada Aspek Pemograman

\begin{tabular}{lll}
\hline No & \multicolumn{1}{c}{ Indikator } & Skor \\
\hline 1 & Tingkat interaksi siswa dengan media & 4 \\
2 & Kemudahan berinteraksi dengan media & 4 \\
3 & Kemudahan pengoperasian media & 4 \\
4 & Kemudahan penggunaan tombol (button) & 5 \\
5 & Efesiensi penggunaan slide & 4 \\
6 & Kesesuaian penggunaan link & 5 \\
7 & Kualitas animasi & 4 \\
8 & Kualitas video & 5 \\
9 & Pemberian umpan balik terhadap siswa & 5 \\
& Jumlah Skor & 40 \\
& Rata-Rata & 4,44 \\
\hline
\end{tabular}

Rerata skor sebesar 4,44 yang termasuk kategori baik. Berdasarkan hasil tersebut model sudah layak untuk diujicobakan. Peneliti mencari kelas perkuliahan yang sudah menerapkan kurikulum KKNI untuk melaksanakan ujicoba. Hal ini dikarenakan materi yang ada pada mata kuliah matematika ekonomi merupakan materi yang tercantum dalam kurikulum KKNI. Dicari waktu yang tepat untuk melaksanakan perkuliahan pada kelas tersebut dengan melihat fasilitas yang ada. Fasilitas yang dimaksud adalah tersedianya alat elektronik seperti laptop, computer, ataupun handphone dan layar proyektor di setiap ruang kelas. Ujicoba dilaksanakan dengan cara penggunaan MISE yang dikemas dalam bentuk aplikasi software perangkat elektronik Software Adobe Flash Profesional CS6 dalam proses pembelajaran oleh dosen. Selama proses pembelajaran menggunakan media, peneliti melakukan observasi terhadap penggunaan media tersebut. Dosen yang telah menggunakan media di dalam proses pembelajaran kemudian diwawancara untuk diminta tanggapan, komentar, dan juga saran mengenai media yang dikembangkan. Dosen yang diwawancara berjumlah 2 orang. Selain dilakukan wawancara terhadap dosen, juga dilakukan wawancara terhadap mahasiswa yang berjumlah 22 orang. Berdasarkan wawancara terhadap dosen dan mahasiswa, media kembali direvisi. Hasil revisi tahap II menghasilkan produk akhir MISE yang dikemas dalam bentuk aplikasi software perangkat elektronik Software Adobe Flash Profesional CS6 pada mata kuliah matematika ekonomi.

Tahap IV. Refleksi Produk Perangkat Pembelajaran

Pada tahap ini media pembelajaran interaktif yang telah selesai dikembangkan kemudian direfleksikan kepada mahasiswa program studi pendidikan ekonomi FKIP Universitas Batanghari. Refleksi ini bertujuan untuk mengetahui respon mahasiswa terhadap media pembelajaran interaktif hasil pengembangan. Dari tahap ini akan diketahui kelayakan media yang dikembangkan. Mahasiswa kemudian diminta mengisi angket responden untuk memberikan tanggapan terhadap media pembelajaran interaktif tersebut.

\section{SIMPULAN}

Berdasarkan hasil dan pembahasan dari penelitian pengembangan ini dapat disimpulkan bahwa: penelitian dan pengembangan ini menghasilkan produk berupa MISE yang dikemas dalam bentuk aplikasi software perangkat elektronik Software Adobe Flash Profesional CS6 pada mata kuliah ekonomi makro untuk mahasiswa program studi pendidikan ekonomi FKIP Universitas Batanghari. Tahapan yang dilakukan untuk menghasilkan MISE yang dikemas dalam bentuk aplikasi software perangkat elektronik Software Adobe Flash Profesional CS6 sebagai berikut: a) Tahap I Analisis Permasalahan di lapangan; b) Tahap II. Pengembangan Desain dan Prototipe Perangkat Pembelajaran Daring Melalui MISE; c) Tahap III. Pengujian dan Penyempurnaan Prototipe Perangkat Pembelajaran Online Melalui MISE; d) Tahap IV. Refleksi Produk Perangkat Pembelajaran. Materi di dalam model pembelajaran terdiri dari delapan sub materi, yaitu: Kajian Ilmu Ekonomi Makro, Abstraksi Perekonomian dan Aliran-aliran ekonomi, Pendapatan Nasional, Pertumbuhan dan Pembangunan Ekonomi, Uang dan Pasar Uang, Inflasi, Kebijakan dan Sistem Perekonomian, Sistem Perbankan, Perekonomian Tertutup dan Terbuka, Keseimbangan Perekonomian, Neraca Pembayaran, Saving, Investasi, dan Konsumsi, Employment dan Unemployment dan Business Cycles. Pada setiap materi mahasiswa akan diminta terlibat aktif dalam pembelajaran. Media pembelajaran yang dikembangkan juga dilengkapi dengan soal latihan pada akhir pembelajaran untuk evaluasi.

Selain itu berdasarkan validasi ahli materi dan ahli media pembelajaran interaktif, dapat diketahui hasil validasi ahli materi sebesar 4,5 atau baik dan hasil validasi ahli media sebesar 4,44 atau baik. Hasil wawancara dengan dosen dan mahasiswa secara keseluruhan menunjukkan tanggapan yang baik terhadap penggunaan MISE yang dikemas dalam bentuk aplikasi software perangkat elektronik Software Adobe Flash Profesional CS6 dalam proses pembelajaran. Adapun impilkasi yang diperoleh dari penelitian ini yaitu 1) MISE yang dikemas dalam bentuk aplikasi software perangkat elektronik Software Adobe Flash Profesional CS6 hasil pengembangan dapat digunakan dalam pembelajaran ekonomi makro karena memuat materi dalam kurikulum KKNI. 2) MISE yang dikemas dalam bentuk aplikasi software perangkat elektronik Software 
Adobe Flash Profesional CS6 dapat membantu dosen dalam menyampaikan materi pada mata kuliah ekonomi makro. MISE yang dikemas dalam bentuk aplikasi software perangkat elektronik Software Adobe Flash Profesional CS6 juga dapat menarik minat dan motivasi mahasiswa dalam mengikuti kegiatan pembelajaran. Hal tersebut berdasarkan hasil observasi penggunaan model dan juga sesuai dengan komentar dosen dan mahasiswa saat wawancara.

\section{DAFTAR PUSTAKA}

Abdallah, M. M. S. 2011. Web-based new literacies and EFL curriculum design in teacher education: A design study for expanding EFL student teachers' language-related literacy practices in an Egyptian pre-service teacher education programme. $\mathrm{PhD}$ Thesis. Graduate School of Education, College of Social Sciences and International Studies, University of Exeter, UK.

Arsyad, Azhar. 2013' Media Pembelajaran. Jakarta: PT. RajaGrafindo Persada

Atapukang, Nurmasa. 2016. Kreatif Membelajarkan Pembelajar Dengan Menggunakan Media Pembelajaran Yang Tepat Sebagai Solusi Dalam Berkomunikasi. Jurnal Media Komunikasi Geografi. Vol. 17, Nomor 2, Desember

Bakti, T. Diana, Rakhmat Sumanjaya, dan Syahrir Hakim Nasution, 2010. Pengantar Ekonomi Makro, Medan: USU Press

Daryanto. 2013. Inovasi Pembelajaran Efektif. Bandung: Yrma Widya.

Dornbusch, Rudiger and Fisher, Stanley. 1996. Makro Ekonomi Edisi Keempat cetakan Kelima. Alih Bahasa, Julius A Mulyadi. Jakarta: Erlangga

Ekayani, Ni Luh Putu. 2017. Pentingnya Penggunaan Media Pembelajaran Untuk Meningkatkan Prestasi Belajar Siswa. Artikel Jurusan PGSD, Fakultas Ilmu Pendidikan Universitas Pendidikan Ganesha.

Hamzah, Nina Lamatenggo. 2011. Teknologi Komunikasi \& Informasi Pembelajaran. Jakarta: PT. Bumi Aksara.

Ikhwandi, Ilham Eka dan Basri, Irma Yulia. 2020. Perancangan Media Pembelajaran Interaktif Konsep Dasar Kelistrikan Pada Mata Kuliah Listrik dan Elektronika. JTEV (JURNAL TEKNIK ELEKTRO DANVOKASIONAL) Volume 06 Number 022020 ISSN: 2302-3309

Nurdyansyah, dan Eni Fariyatul Fahyuni. 2016. Inovasi Model Pembelajaran. Sidoarjo: Nizamia Learning Center, cet: 1

Reeves, T. C. (2000). Socially responsible educational technology research. Educational Technology, 40(6), 19-28.
Rusman, Deni Kurniawan dan Cepi Riyana, 2013. Pembelajaran Berbasis Teknologi Informasi dan Komunikasi. Jakarta: Raja Grafindo Persada

Sadikin, Ali \& Hamidah, Afreni. 2020. Pembelajaran Daring di Tengah Wabah Covid-19. Biodik: Jurnal Ilmiah Pendidikan Biologi. 6 (2): 214-224.

Sanaky, AH Hujair. 2013. Media Pembelajaran Interaktif-Inovatif. Yogyakarta: Kaubaka Dipantara

Setiawan, Andi M. 2017. Belajar dan Pembelajaran. Ponorogo: Uwais Inspirasi Indonesia

Suryowinoto, Andy. 2020. Pengembangan Media Pembelajaran Interaktif Elektronika Digital.. Jurusan Pendidikan Teknik Elektro-Fakultas Teknik Universitas Negeri Surabaya (UNESA)

Tarigan, D dan Siagian, Sahat. 2015. Pengembangan Media Pembelajaran Interaktif Pada Pembelajaran Ekonomi. Jurnal Teknologi Informasi \& Komunikasi dalam Pendidikan (Vol.2, No. 2). Hlm 187-200.

Umar. 2014. Media Pendidikan: Peran dan Fungsinya dalam Pembelajaran. Jurnal Tarbawiyah Volume 11Nomor 1 Edisi Januari-Juli 2014

Walker, D.F \& Hess, R.D. 1984. Instructional Softwere: Principal and Prespectives for Design and Use. California: Wadsworth, Inc 